811.163.41'42:32

https://doi.org/10.18485/sj.2017.22.1.12

СВЕТЛАНА СЛИЈЕПЧЕВИТ ${ }^{*}$ Институт за српски језик САНУ Београд
Оригинални научни рад

Примљен: 03. 10. 2016.

Прихваћен: 15. 12. 2016.

\title{
О ЕЛЕМЕНТИМА ХАГИОГРАФИЈЕ У ЈЕДНОМ ТИПУ ПОЛИТИЧКИХ ЛЕТАКА**
}

Предмет овог истраживања јесу леци у којима се износе биографије политичких кандидата. Циљ рада јесте указати на језичко-стилске маркере којима се хагиографија и биографија политичког кандидата жанровски приближавају. Полази се од хипотезе да су елементи хагиографије инкорпорирани у политички летак не из стилских, већ из манипулативних разлога.

Кључне речи: политички дискурс, летак, хагиографија

\section{1. ПРЕГЛЕД СЕЛЕКТОВАНЕ ЛИТЕРАТУРЕ}

Летак је, као средство политичког комуницирања, у односу на плакат, касније почео да се јавља, нарочито на нашем говорном подручју.

Прва кампања у којој су се масовно користили леци датира још из периода 1583-1594. године, из времена када се водила политичка борба између католика и протестаната у Паризу и Лиону (Сојер 1990: 15-16). Џефри Сојер, истраживач пропагандних летака објављиваних у Француској с почетка 17.

*s.slijepcevic@gmail.com

** Овај рад је настао у оквиру пројекта 178009 Лингвистичка истражсивања савременог српског књижевног језика и израда Речника српскохрватског књижевног и народног језика $C A H У$, који у целини финансира Министарство просвете, науке и технолошког развоја Републике Србије. 
века, истиче да је још француски владар Луј XIII препознао политичку моћ летака, те је из периода његове владавине остало сачувано 3417 летака (Сојер 1990: 1).

Летак се често дефинише као плакат мањих димензија (Архивски стандарди и поступии Држсавног архива Квебека, према Лакић 1996: 83). Међутим, ова дефиниција се може само условно узети у обзир, будући да нека истраживања указују на већи број дистинктивних црта (нпр. Лукежић 2007; Симић 2012), а затим и наша грађа показује да су се леци толико развили да показују отвореност према многим другим, развијенијим жанровима, што примећује и Ирвин Лукежић, који се бавио лецима као претечама данашњих новина. Наиме, овај аутор закључује да састављачи летака неретко посежу за различитим жанровима и стилским средствима: поезијом, дијалогом, писмима, сатиром, басном, травестијом и сл. (Лукежић 2007: 14).

Неретко се, с правом, истиче да су леци, и у архивама и у истраживањима, запостављени, јер припадају тзв. сивој литератури, литератури која се умножава, а не дистрибуира уобичајеним каналима (Лакић 1996: 79), дакле, оној врсти која се масовно производи у одређене сврхе и углавном нема података о ауторству, издању, тиражу, штампи и сл.

Када је реч о употреби, Бирд тврди да се плакати употребљавају чешће него леци зато што постоји могућност да се леци баце, док су плакати, нарочито на билбордима, уочљивији, те да и више пажње привлаче (Бирд 1999: 74). С друге стране, Ирвин Лукежић сматра да је летак погодан за масовну популаризацију идеја у најширим друштвеним слојевима управо зато што је његова преносивост и доступност омогућена великим тиражом и малим димензијама (Лукежић 2007: 16).

\section{2. КОРПУС}

Наш корпус, који обухвата изборне кампање од 1990. до 2014. године, показује да су леци у политичке сврхе на нашим просторима масовније почели да се употребљавају од изборне кампање 1997. године, а да се пре тога јављају спорадично. Готово све партије користиле су летке у кампањама од 2000. године па надаље као једно од средстава не само за рекламирање већ и за информисање грађана о политичким програмима, циљевима и идејама. Наиме, од 2000. године већина летака није идентична плакатима, све чешће се јављају различите врсте летака са развијенијим текстовима, боље графички уређени леци, с богатијим и визуелним и текстовним садржајем ${ }^{1}$. Овакве врсте

${ }^{1}$ Вера Васић наводи опште карактеристике летака на основу истраживања спроведеног на корпусу летака из изборне кампање 2008. године, а оне се углавном односе на прототипичне 
летака отварају се за другачије жанрове у оквиру политичког дискурса, али и других дискурса: на лецима се штампају интервјуи, политички програми, биографије кандидата и сл. Количина текста условљава развијенију форму, те се јављају и читаве брошуре штампане и на четири стране.

\section{3. ПРЕДМЕТ, ЦИЉ И ХИПОТЕЗА}

У овом раду, фокус је на једном типу летака, тј. лецима у којима се износи биографија политичког кандидата која је дијалогична са хагиографијом. Овај тип летака фреквентан је у председничким изборним кампањама. Биографија кандидата је углавном прошарана политичким циљевима и резултатима, као и идеалистичким описима.

Бранко Тошовић биографије сврстава у стил персоналних докумената у оквиру административног функционалног стила, а под аутобиографијама подразумева биографије писане у првом лицу, чији је садржајни оквир близак административном стилу, а начин изражавања књижевном (Тошовић 2002: 374), али биографије политичара изнете у лецима одступају од типичног жанра, а та одступања индукују стилске и комуникативне последице. С тим у вези јесте и наша основна хипотеза, а то је да се жанровска одступања врше ради манипулације. Ову хипотезу потврђујемо детаљнијом анализом једног примера биографије из изборне кампање 2000. године, с циљем да покажемо да су хагиографски елементи инкорпорирани у ову биографију како би се,

летке: „У флајерима на српском језику већина странака употребљава готово доследно само једно писмо, поједине су исти флајер штампале и ћирилицом и латиницом, а неке су у истом флајеру употребљавале оба писма. Таква употреба писама у флајерима у српском језику одражава уставне формулације, с једне стране, придавање симболичне вредности изабраном писму, уважавање заступљености, или претпостављене заступљености писама у појединим регијама, или пропагандно-маркетишки потез, с друге” (Васић 2011: 209), затим: „Димензије флајера - лист папира половине или четвртине A4 формата, најчешће, сложен на неколико начина (по трећини, половини висине и окренут за 90 и сл.), а ређе повезана 2-3 листа - одређују обим и прелом текста, а тиме и број информација, заступљеност кодова, графички дизајн. Податак о страници, назив и лого, налази се обавезно на насловној страници, а најчешће и на задњој. Како је број странака које су 2008. године учествовале на парламентарним и локалним изборима био велик, уз назив је често стајао и број под којим се странка налази на гласачком листићу, што је некима омогућило да искористе његову симболичку вредност, а неке подстакло да директно подуче гласаче" (Васић 2011: 210). Ови општи елементи варирају у зависности од врсте летка, а наш корпус показује да постоји чак десет различитих врста: летак-плакат, летак-контекст, летак-извештај, летак-захтев, летак-биографија, летак-програм, летак-тема, летак-обраћање, летак-најава и мешовити тип летка. О боји и употреби логотипа странке, Васић додаје: „Боја флајера по правилу одговара бојама заставе и лога странке, које се комбинују на више начина: боја подлоге и боја слова, боја броја (редно место на бирачком списку) и круг око њега, чиме се информација о странци понавља и утврђује" (Васић 2011: 211). Сва њена запажања тичу се углавном прва два поменута типа, док су у осталим типовима летака варијантна. 
с једне стране, изградио култ личности, а с друге стране, ефекат на гласаче био јачи.

\section{4. АНАЛИЗА}

\section{Наводимо транскрипт летка из изборне кампање 2000. године:}

Ко је Војислав Коштуница ?

Почетак - Породица Коштуница потиче из села Коштунићи (Равна Гора) код Горњег Милановца. Отац Јован био је адвокат и судија, мајка Радмила (Аранђеловић), домаћица.

Откуда презиме Коштуница? - Прадеда Војислава Коштунице био је Јован Дамљановић, и за време Милоша Обреновића био је члан тадашње скупштине, односно Совјета. Пошто га Милош, кад би му се обратио, према имену села почео звати Коштуница, то му је остао надимак. Временом је тај надимак постао презиме Дамљановића. Коштунице од оснивања Србије учествују у политичком животу. Исти тај прадеда, Јован Дамљановић-Коштуница, био је учесник Светоандрејске скупштине. Војин отац, Јован Коштуница, после Другог светског рата долази у сукоб с ондашњим властима, остаје без посла и продаје кућу у Горњем Милановцу. Породица Коштуница прелази у Београд где од тада живи.

Националност - За себе каже: „Србин сам и православац. То је моје биће и моја основна одредница. То није став - јер ставови могу да се мењају. Српство је осећај и унутрашња потреба". Оптужен да је ултранационалиста бранио се причом да ДСС није никад говорила да ће границе српских земаља бити тамо где су српске јаме и гробови, али и упозорио: „Ми Југославију нисмо разбили, али не смемо дозволити да она разбије нас. Ако ми не сачувамо српску државу други је за нас неће чувати".

Образовање - Гимназију је завршио у Београду, матурирао је 1962. Правни факултет је завршио 1966, магистрирао 1970, а докторирао 1974. године с тезом „Институционализована опозиција у политичком систему капитализма".

Каријера-Војислав је био асистент на Правном факултету од 1970. до 1974. године. У јавности се појавио 1971. кад је стао на страну професора Милоша Ђурића, кога су комунисти напали због противљења променама Устава СФРЈ. Због жестоког и доследног оспоравања преднацрта Устава из 1974. - устава који ће касније омогућити распад земље, Коштуница је платио високу цену - избацили су га с факултета. Доследност је показао и двадесет година касније када су га позвали да се врати на факултет пошто је доказана погубност званичне политике из седамдесетих - одбио је говорећи да га не могу исти људи избацивати и примати као да се ништа није догодило.

Осамдесетих година ангажује се у одбору за заштиту слободе мисли и изражавања, заједно с Добрицом Ћосићем, Костом Чавошким, Палавестром, Тадићем...

Страначки ангажман - Никада није био члан СК, али се никада није том чињеницом разметао. „То што нисам био у партији било је природно и мени и комунистима. За њих је решавање неког проблема увек било средство а не циљ”, рекао је 1994, а по оснивању ЈУЛ-а додао: „Петокрака и ружа, две комунистичке партије за једну државу су заиста много".

Мало је познато да управо Коштуница, 1989. године, у свом стану у Београду, са групом пријатеља, оснива Демократску странку (ДС). Сећа се: „Први разговори о стварању Демократске странке започели су у кругу пријатеља где су били Коста Чавошки, Леон Којен и ја... Мислили смо да ће питање ко води странку бити неважно, били смо прави идеалисти". Због нејасног одређења ДС према националном питању, 1992. године, с групом истомишљеника ствара нову странку - Демократску странку Србије (ДСС). Из 
овог периода датирају неоправдане оптужбе на рачун Коштунице да уништава демократску опозицију и да ствара странку која не може да преживи прве изборе. Показало се да критичари нису били у праву. ДСС тада добија и популарни надимак - шљиварска странка (због плаката ,зрело је” са шљивом као симболом).

Политика - Доследност, доследност и доследност... Једини није „ишао код Слобе”, није био на Цетињу на Милову Инаугурацију, није оклевао да напада погрешну политику ни Америке ни Русије. Доследност се огледа и у критици црногорских вођа да (и Момир и Мило) желе самосталну државу.

Популарност - С обзиром да је правник, често га питају да процени ово и оно, и често његова предвиђања буду тачна. Александар Тијанић и други „оштројезики” новинари једино њему одају поштовање, а Тијанић га назива факиром српске опозиције и прогнозира скори успех (браћа Тарабићи у Креманском пророчанству давно су прорекли да ће на челу Србије бити човек чије је презиме исто као и назив села из кога потиче).

Многи му замерају да је превише интелектуалан у обраћању народу, али истичу и један феномен - његове поруке највише прихвата обичан свет. У предизборним анкетама Коштуница добија највише гласова управо као прототип потребног политичара на овдашњим просторима.

Познато је да му је мачка кућни љубимац, што је вешто злоупотребио Шешељ у кампањи блаћења ДСС и самог Коштунице, али је мање познато да их више воли његова супруга, Зорица, него он.

Коштуница је познат и као једини председник странке који нема лично обезбеђење. „Са обезбеђењем се не бих осећао безбедно” - изјавио је. Иначе, бели југо 60 из 1990. године једино је возило које он и његова супруга поседују.

Одговорност - На питање шта би урадио када би био председник Србије, изјавио je: „Најпре бих окупио најумније људе Србије и од њих затражио савет шта да чиним. А у спољној политици бих преговарао, преговарао и преговарао. Наша девиза мора бити - ни рат ни капитулација, Србија се мора сачувати".

Ова биографија почиње формом упитника, али ова форма није спроведена до краја. Као делови биографије издвајају се: националност, образовање, каријера, политички и страначки ангажман, личне особине и сл. Дакле, један део јесте биографског типа, док је већи део заправо подређен стварању култа личности. Том грађењу култа личности овде су подређена сва језичка и стилска средства.

Условно се овај текст може поделити на десет целина, које почињу питањем (ко је Војислав Коштуница, откуд презиме Коштуница и сл.) или речју и синтагмом које најављују тему (начионалност, каријера, страначки ангажман). Међутим, у језичком смислу најзанимљивије су смене чисто информативних исказа (асертива) са изразито експресивним, лично обојеним исказима пуних извештачених израза нулте семантике (Србин сам и православаи. То је моје биће и моја основна одреднииа. То није став - јер ставови могу да се мењају. Српство је осећај и унутрашња потреба.). На лексичком нивоу, карактеристичне су оказионалне и необичне конструкције: оштројезики новинари, факир српске опозииије, као и разговорне фразе и конструкције: једини није ишао код Слобе, платио високу иену, питају га да процени ово и оно. 
Манипулативни циљеви у овом примеру првенствено се остварују тако што ова биографија према многим својим структурним и композиционим елементима прераста у хагиографију. Наводимо овде дефиницију хагиографије коју доноси Речник књижевних термина.

ХАГИОГРАФИЈА (гр. agios - свет; grafos - писати), биографија или живопис хришћанских светаца која практично настаје са појавом хришћанства. Почеци х., као засебног књижевног жанра повезани су са писаним сведочанствима о првим прогонима хришћана - мартиријима. Са своје стране, мартирији представљају прераду записника са саслушања страдалника, и у том смислу много дугују овој судској форми. Иако су по обиму невелики и сасвим сведеног приповедања, са прихватањем хришћанства и развојем званичне религиозне књижевности мартирији све више показују унутрашњу тежњу за романсирањем садржаја судских и архивских списа и ширењем нарације. Њихова схема може се свести на неколико најважнијих момената: почиње са навођењем имена личности о чијим се мучењима сведочи, затим се одређује време када се то дешава (у време владавине неког римског цара), онда следи средишњи део - саслушање страдалника које се развија кроз жив дијалог између њега и представника власти (често самог цара), његова беседа којом пропагира веру, па молитва, мучење, смрт и чуда. Осим мартирија, на уобличавање х., утицале су и античке биографије знаменитих људи какве су писали Ксенофонт и Плутарх. Из ове традиције х. преузима пре свега тежњу за веродостојним приказивањем живота светог, што се огледа и у хронолошком сликању његовог одрастања, сазревања, бележењу стварних чињеница, историјских догађаја и сл. [...] У њој је у први план истакнута дидактичка намена дела, чији је циљ и да васпитава и да пружи морални образац понашања.

Наиме, заједничке црте за дати летак-биографију и хагиографију наводимо табеларно (табела 1), поткрепљујући конкретним примерима из анализираног текста:

Табела 1. Хагиографски елементи у летку-биографији

\begin{tabular}{|c|c|}
\hline ХАГИОГРАФИЈА & ЛЕТАК-БИОГРАФИЈА \\
\hline $\begin{array}{l}\text { 1. Почиње навођењем имена и поре- } \\
\text { клом, као и историјским догађајима } \\
\text { за које се везује порекло }\end{array}$ & $\begin{array}{l}\text { Ко је Војислав Кочтуница? } \\
\text { Почетак - Породица Коштуница потиче } \\
\text { из... } \\
\text { Откуда презиме Коштунииа? - Прадеда } \\
\text { Војислав... после Другог светског рата... }\end{array}$ \\
\hline 2. а. Средишњи део дијалошки & $\begin{array}{l}\text { смена питања и одговора, с доста цитата без } \\
\text { навођења извора цитата }\end{array}$ \\
\hline
\end{tabular}




\begin{tabular}{|c|c|}
\hline $\begin{array}{l}\text { 2. б. Средишњи део о мучењима, с } \\
\text { потком судског извештаја }\end{array}$ & $\begin{array}{l}\text { У тексту биографије муке су изражене ко- } \\
\text { ришћењем експресивно маркиране лексике } \\
\text { с негативном конотацијом, разговорне лек- } \\
\text { сике и сл., као и терминологије из области } \\
\text { судства: } \\
\text { Оптужен да је ултранационалиста бранио } \\
\text { се.. } \\
\text { Комунисти напали због противљења про- } \\
\text { менама... } \\
\text { Избацили су га с факултета... }\end{array}$ \\
\hline $\begin{array}{l}\text { 2. в. Средишњи део беседнички, } \\
\text { најчешће о вери }\end{array}$ & $\begin{array}{l}\text { - Србин сам и православац. То је моје биће и } \\
\text { моја основна одредница. То није став - јер } \\
\text { ставови могу да се мењају. Српство је осећај } \\
\text { и унутрашња потреба. } \\
\text { - Ми Југославију нисмо разбили, али не } \\
\text { смемо дозволити да она разбије нас. Ако ми } \\
\text { не сачувамо српску државу други је за нас } \\
\text { неће сачувати. }\end{array}$ \\
\hline $\begin{array}{l}\text { 2. г. Хронолошко сликање одрастања } \\
\text { и бележења стварних чињеница }\end{array}$ & $\begin{array}{l}\text { Гимназију завршио... } \\
\text { Докторирао 1974. године... } \\
\text { Војислав је био асистент... } \\
\text { Оснива Демократску странку... }\end{array}$ \\
\hline 3. Завршни део о чудима & $\begin{array}{l}\text { Позивање на туђе оцене: } \\
\text { Тијанић га назива факиром српске опозиције } \\
\text { и прогнозира скори успех } \\
\text { Позивање на пророчанство: } \\
\text { Браћа Тарабићи Креманском пророчанству } \\
\text { давно су прорекли да ће на челу Србије бити } \\
\text { човек чије је презиме исто као и назив села } \\
\text { из кога потиче. }\end{array}$ \\
\hline
\end{tabular}




\begin{tabular}{|c|c|}
\hline $\begin{array}{l}\text { 4. Истицање врлина у дидактичке } \\
\text { сврхе }\end{array}$ & $\begin{array}{l}\text { Доследност: } \\
\text { Због жестоког и доследног оспоравања... } \\
\text { Доследност је доказао и двадесет година } \\
\text { касније... } \\
\text { Никада није био члан... } \\
\text { Доследност, доследност, доследност... } \\
\text { Доследност се огледа и... } \\
\text { Једини није... } \\
\text { Наивност: } \\
\text { Мислили смо да ће питање ко води странку } \\
\text { бити неважно, били смо прави идеалисти. } \\
\text { Љубав према животињама: } \\
\text { Познато је да му је мачка кућни љубимаи... } \\
\text { Скромност: } \\
\text { Бели југо бо из 199о. године једино је возило } \\
\text { које он и његова супруга поседују. }\end{array}$ \\
\hline
\end{tabular}

Уочљиво је да се хагиографски елементи мешају с биографским не само у погледу структуре (редослед композиционих целина исти је и за хагиографију и за биографију), већ и на нивоу суптилног грађења култа личности преко метафора и метафоричних конструкција. Наиме, Јована Диковић примећује групу месијанских метафора на основу којих се гради култ личности, њени примери садрже конструкције као што су Он је пророк и мисионар српске културе... Вукова мисија и сл., док се у овом тексту летак издвајају примери који указују на политичког кандидата као чувара, заштитника, мученика: факир српске опозииије, Ако ми не сачувамо српску државу други је за нас неће чувати, У јавности се појавио 1971. кад је стао на страну професора Милоша Ђурића, кога су комунисти напали због противљења променама Устава СФРЈ, Кочтуница је платио високу чену, није оклевао да напада погрешну политику ни Америке ни Русије, а чак се указује и на његове пророчке способности: често његова предвиђања буду тачна. 


\section{5. ЗАКЉУЧАК}

Структура хагиографије у летку-биографији резултат је намере да се политички кандидат глорификује и представи у што бољем светлу. Овим указивањем на сличности не сугеришемо да је творац летка упознат са жанром хагиографије нити да су заједничке црте последица намере да биографија личи на хагиографију, али сматрамо да је значајно било скренути пажњу на све сличности, јер се пред будућа истраживања може поставити специфичан циљ - наћи универзалне пропагандне принципе у различитим жанровима, будући да је познато да се пропаганда коју данас познајемо понајвише као политичку развила из верске пропаганде и да на другим пољима ${ }^{2}$ постоје већ истраживања која указују на заједничка средства у различитим идеологијама.

\section{ЛИТЕРАТУРА}

Васић 2011: Vera Vasić, Modeli kontekstualizacije izbornih flajera, $u$ : V. Vasić (ur.), Primenjena lingvistika u čast Ranku Bugarskom, Jezik u upotrebi, Novi Sad: Društvo za primenjenu lingvistiku Srbije, Filozofski fakultet Univerziteta u Novom Sadu, Filološki fakultet Univerziteta u Beogradu, 201-219.

Диковић 2010: Јована Диковић, Метафоре у политичком дискурсу, Гласник Emнографског института САНУ, књ. 58, св. 1, Београд, 141-156.

Лакић 1996: Zdenka Lakić, Mogućnost primjene međunarodnog standardnog bibliografskog opisa neknjiževne građe pri obradi zbirke plakata i letaka u arhivu, Arh. vijesti, god. 39, 75-89.

Лукежић 2007: Irvin Lukežić, Riječki letak kao oblik učene i pučke književne tradicije, Fluminensia, god. 19, br. 1, 13-34.

PКT: Речник књижевних термина, Институт за књижевност и уметност у Београду, Београд: Нолит, 1986.

Рабреновић 2013: Andrijana Rabrenović, Politički plakat i kult ličnosti, Medianali, Vol. 1, No. 13, Dubrovnik, 71-101.

Симић 2012: Радоје Симић, Изборна кампања 2012. - понижење језика У: М. Ковачевић (ур.), Савремено друштво и криза проучавања језика

\footnotetext{
${ }^{2}$ Примера ради, Рабреновић се бави политичким плакатима као средством за формирање и развијање култа личности и закључује да су средства иста независно од идеологије (Рабреновић 2013: 74), али се њена истраживања заснивају се на анализи невербалних компоненти плаката.
} 
и књижевности, Крагујевац: Филолошко-уметнички факултет, $195-210$.

Cojep 1990: Jeffrey Sawyer, Printed poison: pamphlet propaganda, faction politics, and the public sphere in early seventeenth-century France, Berkeley: University of California press.

Тошовић 2002: Бранко Тошовић, Функиионални стилови, Београд: Београдска књига.

\section{THE COMMON FEATURES FOR FLYER-BIOGRAPHY AND HAGIOGRAPHY}

\section{Summary}

This paper is focused on flyers with political candidate's biography. Our aim is to show the stylistic and linguistic features that are common for flyer-biography and hagiography. One of the main aims of our paper is to indicate (show) how the most of stylistic and linguistic characteristics are used in a manipulative and persuasive way in this type of common political propaganda genre.

Svetlana Slijepčević 